\title{
Correlation between Vitamin C Deficiency and Hydroxyproline Amino Acid in Young Children of Northern Part in Palestine
}

\author{
Maen Mahfouz ${ }^{1}$, Ismail Masri' ${ }^{2}$, Haneen Mahfouz ${ }^{3}$, Yara Mahfouz ${ }^{4}$ \\ ${ }^{1}$ Department of Orthodontics and Pediatric Dentistry, Dental School, Arab American University, Jenin, Palestine \\ ${ }^{2}$ Department of Basic Biomedical Sciences, Dental School, Arab American University, Jenin, Palestine \\ ${ }^{3}$ Biomedical Department, Central Public Health Lab, Palestinian Ministry of Health, Ramallah, Palestine \\ ${ }^{4}$ Dental Department, Al Zafer Hospital, Najran, Saudi Arabia \\ Email: maenmahfouz@gmail.com, ismailmmasri@yahoo.com, haneen medlab@yahoo.com, \\ dr cuteee@yahoo.com
}

Received 10 April 2015; accepted 1 June 2015; published 4 June 2015

Copyright (C) 2015 by authors and Scientific Research Publishing Inc.

This work is licensed under the Creative Commons Attribution International License (CC BY).

http://creativecommons.org/licenses/by/4.0/

c) (7) Open Access

\begin{abstract}
Vitamin $\mathrm{C}$ is a water soluble vitamin found in many natural sources, citric fruits, vegetables, particularly as antioxidants and as a factor to catabolism and metabolism. The aim of this article is to correlate the level of vitamin $C$ and the hydroxyproline level in urine samples among young palestinian children from age 5 - 14 years. Materials and Methods: Urine samples of 34 individuals of both sexes, their ages ranged from 5 - 14 years were collected and analyzed for determination of Urinary Hydroxyproline by using Modified Neuman and Logan Method. The result of this study shows a significant correlation between Vitamin $C$ and Hydroxyproline at level 0.01 . The conclusion of this study was that low vitamin $C$ intake was found among young palestinian children from age 5 - 14 years, Vitamin $C$ should be supplemented in the drinks taken by young palestinian children from age 5 - 14 years as well as further research and investigation with large samples required to include all children from middle and southern Palestine.
\end{abstract}

\section{Keywords}

Vitamin C, Hydroxyproline, Palestinian Children

\section{Introduction}

Vitamin C is a water soluble vitamin found in many natural sources, citric fruits, vegetables a particularly as an-

How to cite this paper: Mahfouz, M., Masri, I., Mahfouz, H. and Mahfouz, Y. (2015) Correlation between Vitamin C Deficiency and Hydroxyproline Amino Acid in Young Children of Northern Part in Palestine. Open Journal of Pediatrics, 5, 151-155. http://dx.doi.org/10.4236/ojped.2015.52023 
tioxidants and as a factor to catabolism and metabolism [1].

From the earliest descriptions of scurvy, the disease caused by vitamin C deficiency, it was evident that there were effects on connective tissues, especially in healing wounds [2]. The history of experiments that led to the conclusion that collagen metabolism was affected by the disease and that formation of hydroxyproline, animino acid found almost uniquely in collagen, might be involved was reviewed extensively [3] [4].

Many of the clinical problems associated with ascorbic acid deficiency, such as abnormalities of the skeleton seen in infantile scurvy [5], the lesions of the gingiva [6] [7], as well as the impairment of wound healing and faulty healing of bony fractures [5] [8] [9], are related to alterations in collagen metabolism.

The relationship between vitamin C and collagen is well established and lies in the hydroxylation of proline and lysine residues in the preformed protocollagen molecule [10] [11].

The aim of this article is to correlate the level of vitamin $\mathrm{C}$ and the hydroxyproline level in urine samples among young palestinian children from age 5 - 14 years.

\section{Materials \& Methodology}

This study has been carried out on 34 individuals of both sexes their ages ranged from 5 - 14 years between 2013 and 2014. The sample randomly selected from out patients attending department of orthodontics and pediatric Dentistry at the faculty of dentistry_-Arab American university—jenin in northern part of Palestine.

Inclusions criteria were healthy patients older than 5 years till 14 years, with ASA class I and no supplemental vitamin C intake. Unhealthy patients with ASA class II, III, IV, V and using supplemental vitamin c drugs were considered as exclusion criteria.

Ethical approval, this study registered and approved by the biomedical department at dental faculty of Arab American university in which all records of the samples were examined. Parental informed consent was carried out for each subject involved in this study by using a written form.

Case history had been taken for each subject and Clinical Examination carried out on dental chair for each subject who seated in reclining position. Plain mirrors, blunt probes (0.6 - $0.7 \mathrm{~mm}$ in diameter). Arab American university-jenin Assessment forms (2010) used.

The collected Urine samples were analyzed as the following:

Determination of Urinary Hydroxyproline:

Method Modified Neuman and Logan [12].

Principle: Hydroxyproline is treated with $\mathrm{CuSO}_{4}$ and $\mathrm{H}_{2} \mathrm{O}_{2}$ in alkaline solution, this results in the formation of pyrroline-4-carboxylic acid.

Acidification is converted to pyyrole-2-carboxylic acid.

The later condenses with P-dimethylaminobenzaldehyde to give a coloured complex which is measured at $540 \mathrm{~nm}$ (Table 1).

Reagents:

1) Copper sulphate (0.01 M): Dissolve $0.159 \mathrm{~g}$ of it in $100 \mathrm{ml}$ Distilled water.

\begin{tabular}{ccccc}
\hline Table 1. Procedure. & & & \\
\hline S.N & Reagent/Sample & Blank & Standard & Test \\
\hline 1 & Urine & & & $1 \mathrm{ml}$ \\
2 & Standard & & $1 \mathrm{ml}$ & \\
3 & Distilled Water & $1 \mathrm{ml}$ & \\
4 & $\mathrm{CuSO}_{4}(0.01) \mathrm{M}$ & $1 \mathrm{ml}$ & $1 \mathrm{ml}$ & $1 \mathrm{ml}$ \\
5 & $\mathrm{NaOH}^{(2.5) \mathrm{M}}$ & $1 \mathrm{ml}$ & $1 \mathrm{ml}$ & $1 \mathrm{ml}$ \\
6 & $6.6 \% \mathrm{H}_{2} \mathrm{O}_{2}$ & $1 \mathrm{ml}$ & $1 \mathrm{ml}$ & $1 \mathrm{ml}$ \\
7 & $3 \mathrm{~N} \mathrm{H}_{2} \mathrm{SO}_{4}($ with agitation) & $4 \mathrm{ml}$ & $4 \mathrm{ml}$ & $4 \mathrm{ml}$ \\
8 & $5 \% \mathrm{P}_{\text {-dimethylamionbenzaldehyde }}$ & $2 \mathrm{ml}$ & $2 \mathrm{ml}$ & $2 \mathrm{ml}$ \\
\hline
\end{tabular}


2) Sodium Hydroxide (2.5 N): Dissolve $10 \mathrm{~g}$ of it in $100 \mathrm{ml}$ distilled water.

3) $6 \%$ hydohen peoxide

4) Sulpharic acid (6 N).

5) P-dimethylaminobenzaldehyde (5\% solution in n-propanol).

6) Hydroxyproline standard: A series of it corresponding to 5, 10, 15, 20, 25, 30, 35, 40, 45 microgram of it are prepared.

The solution are mixed and shaken occasionally during a period of 5 minutes, and then placed in water bath at $80^{\circ} \mathrm{C}$ for 5 minutes with frequent vigrous shaking. The heating and shaking destroys the excess of peroxide. Traces of peroxide, which remain, will decrease color formation and produce an orange-red hue. The tubes are chilled in an ice water bath and then added.

The tubes are placed in water bath at $70^{\circ} \mathrm{C}$ for 16 minutes and then placed in tap water. Read the color at 540 nm.

1) Hydroxyproline is estimated in ug/dl of urine and creatinine is estimated in $\mathrm{mg} / \mathrm{dl}$ of urine.

2) Urine creatinine is estimated in micro cuvette by Jeff's reaction.

Statistical assessment was carried out using SPSS software version 20.0 (SPSS Inc., Chicago, IL, USA). Pearson Correlation test was used to define the correlation between vitamin $\mathrm{C}$ and hydroxyproline amino acid.

\section{Results}

This study aimed to correlate the level of vitamin $\mathrm{C}$ and the hydroxyproline level in urine samples among young palestinian children from age 5 - 14 years.

The lab value measurements of vitamin $C$ and Hydroxyproline among children from 5 - 14 years of both sexes were taken as shown in Table 2.

The mean value of urine hydroxyproline: creatinine ratio in 35 healthy children of both sexes aged 5 - 14 years old was $0.01 \pm 0.004$.

The findings of this study show a significant correlation between Vitamin C and Hydroxyproline at level 0.01 as shown in Table 3.

\section{Discussion}

The study reported here represents the first comprehensive analysis that correlate the level of vitamin $\mathrm{C}$ and the hydroxyproline level in urine samples among young palestinian children from age 5 - 14 years.

Vitamin C has many vital functions in the body. Humans cannot make vitamin C (ascorbic acid or ascorbate) and must obtain it through the diet or as supplements [13].

A low vitamin $\mathrm{C}$ intake agrees with the observation of direct relationship between vitamin $\mathrm{C}$ and the hydroxyproline which the results of this study confirmed and ascertained as the results of other studies [10] [11].

Modern life from high technology to fast food among young generation health diet raising children from age 5 - 14 years who suffering vitamin C deficiency, most probably due to the artificial flavor and coloring had been supplemented to different types of snacks which had been consumed in large quantities by children in school and playing games on TV.

In addition this particular age group of people from 5 to 14 year old has longer outdoors stay at this age leading to greater consumption of in between meals snack food full of fillers, artificial flavor and colors and consequently to be considered at high risk in terms of Vitamin C deficiency.

The extent of the generalisability of the findings from a reasonable small sample is considered to be as a potential limitation and which will lead to further investigations in the future.

This paper is important for pediatric dentists for the following reasons:

1) Dietary advice is an essential part of oral care of children.

2) As our children constantly drinking and snacking, it is very important to be able to give sensible practical advice regarding drinks.

The basic advice is straight forward Vitamin C should be supplemented in the drinks taken by young children.

\section{Conclusions}

1) A low vitamin $C$ intake was found among young palestinian children from age 5 - 14 years, so there should be increase intake of Vitamin C. 
Table 2. Lab value measurements of vitamin C and OH-PR among children from 5 - 14 years of both sexes.

\begin{tabular}{|c|c|c|c|c|c|}
\hline Paient No. & Age years & Gender & Vitamin C N-R 20 - 30 mg/dl & OH-PR N-R $0.01 \pm 0.004$ & Diseases \\
\hline 1 & 5 & M & 22 & 0.03 & \\
\hline 2 & 8 & $\mathrm{~F}$ & 35 & 0.03 & G6PD \\
\hline 3 & 35 & M & 18 & 0.012 & \\
\hline 4 & 10 & $\mathrm{~F}$ & 20 & 0.015 & \\
\hline 5 & 10 & $\mathrm{~F}$ & 32 & 0.021 & \\
\hline 6 & 9 & M & 18 & 0.01 & \\
\hline 7 & 6 & M & 27 & 0.02 & \\
\hline 8 & 13 & M & 24 & 0.015 & \\
\hline 9 & 9 & M & 32 & 0.012 & \\
\hline 10 & 9 & M & 29 & 0.032 & \\
\hline 11 & 10 & M & 25 & 0.032 & \\
\hline 12 & 12 & $\mathrm{~F}$ & 20 & 0.0145 & \\
\hline 13 & 10 & M & 22 & 0.021 & \\
\hline 14 & 7 & F & 25 & 0.033 & \\
\hline 15 & 14 & M & 25 & 0.025 & \\
\hline 16 & 7 & M & 21 & 0.015 & \\
\hline 17 & 9 & F & 29 & 0.0135 & \\
\hline 18 & 8.5 & F & 31 & 0.021 & \\
\hline 19 & 3.5 & M & 31 & 0.012 & \\
\hline 20 & 9 & M & 33 & 0.013 & \\
\hline 21 & 13 & $\mathrm{~F}$ & 25 & 0.015 & \\
\hline 22 & 11 & F & 29 & 0.0135 & \\
\hline 23 & 8.5 & M & 38 & 0.044 & \\
\hline 24 & 7 & M & 27 & 0.02 & \\
\hline 25 & 10 & M & 25 & 0.016 & \\
\hline 26 & 8 & F & 5 & 0.003 & $\begin{array}{l}\text { Vitamin C } \\
\text { Deficiency }\end{array}$ \\
\hline 27 & 11 & F & 15 & 0.008 & $\begin{array}{l}\text { Vitamin C } \\
\text { Deficiency }\end{array}$ \\
\hline 28 & 9 & F & 2 & 0.002 & $\begin{array}{l}\text { Vitamin C } \\
\text { Deficiency }\end{array}$ \\
\hline 29 & 12 & M & 10 & 0.02 & $\begin{array}{l}\text { Vitamin C } \\
\text { Deficiency }\end{array}$ \\
\hline 30 & 13 & F & 5 & 0.0015 & $\begin{array}{l}\text { Vitamin C } \\
\text { Deficiency }\end{array}$ \\
\hline 31 & 13 & $\mathrm{M}$ & 7 & 0.0091 & $\begin{array}{l}\text { Vitamin C } \\
\text { Deficiency }\end{array}$ \\
\hline 32 & 9 & $\mathrm{M}$ & 3 & 0.005 & $\begin{array}{l}\text { Vitamin C } \\
\text { Deficiency }\end{array}$ \\
\hline 33 & 7 & $\mathrm{~F}$ & 8 & 0.004 & $\begin{array}{l}\text { Vitamin C } \\
\text { Deficiency }\end{array}$ \\
\hline 34 & 5 & $\mathrm{M}$ & 5 & 0.002 & $\begin{array}{l}\text { Vitamin C } \\
\text { Deficiency }\end{array}$ \\
\hline
\end{tabular}


Table 3. Correlation between Vitamin C and hydroxyproline amino acid.

\begin{tabular}{cccc}
\hline & & Vitamin C & OH-PR \\
\hline Vitamin C & Pearson Correlation & 1 & $0.696^{* *}$ \\
& Sig. (2-tailed) & & 0.000 \\
N & Pearson Correlation & 34 & 34 \\
SH-PR & Sig. (2-tailed) & $0.696^{* *}$ & 1 \\
& $\mathrm{~N}$ & 0.000 & 34 \\
\hline
\end{tabular}

${ }^{* *}$ Correlation is significant at the 0.01 level (2-tailed).

2) Vitamin C should be supplemented in the drinks taken by young palestinian children from age 5 - 14 years as drinks highly consumed among young palestinian children.

3) Further research and investigation with large samples required to include all children from middle and southern Palestine.

\section{Acknowledgements}

Special thanks to Dr. Ismail Masri for his insights, feedback, and perspectives in hydroxyproline amino acid, as well as special Thanks for 2014 and 2015 graduating Class of faculty of dentistry-Arab American university for their valuable great cooperation and support.

\section{References}

[1] Jacob, R.A. (1990) Assessment of Human Vitamin C Status. American Institute of Nutrition.

[2] Lind, J. (1980) Treatise on the Scurvy. 3rd Edition, Classics of Medicine Library, Birmingham.

[3] Chatterjee, G.C. (1967) Effects of Ascorbic Acid Deficiency in Animals. In: Sebrell Jr., W.H. and Harris, R.S., Eds., The Vitamins, Academic Press, New York, 407-457.

[4] Gould, B.S. (1968) The Role of Certain Vitamins in Collagen Formation. In: Ramachandran, G.N. and Gould, B.S., Eds., Treatise on Collagen, Vol. 2A, Academic Press, New York, 323-365.

[5] Watson, R.C., Grossman, H. and Meyers, M.A. (1980) Radiological Findings in Nutritional Disturbances. In: Goodhart, R.S., Shils, M.E., Eds., Modern Nutrition in Health and Disease, 6th Edition, Lea \& Febiger, Philadelphia, 641-666.

[6] Leggott, P.J., Robertson, P.B., Rothman, D.L., Murray, P.A. and Jacob, R.A. (1986) The Effect of Controlled Ascorbic Acid Depletion and Suppbementation on Periodontal Health. Journal of Periodontology, 7, 480-485. http://dx.doi.org/10.1902/jop.1986.57.8.480

[7] Buzina, R., Aurer-Kozelj, J., Srdak-Jorgic, K., Buhler, E. and Gey, K.F. (1986) Increase of Gingival Hydroxyproline and Proline by Improvement of Ascorbic Acid in Man. International Journal for Vitamin and Nutrition Research, 56, 367-372.

[8] Wolfer, J.A., Farmer, C.I., Carroll, W.W. and Manshardt, D.O. (1947) An Experimental Study of Wound Healing in Vitamin C Depleted Human Subjects. Surgery, Gynecology, and Obstetrics, 84, 1-15.

[9] Hodges, R.E. (1980) Ascorbic Acid. In: Goodhart, R.S. and Shils, M.E., Eds., Modem Nutrition in Health and Disease, 6th Edition, Lea \& Febiger, Philadelphia, 259-273.

[10] Barnes, M.J. and Kodicek, E. (1972) Biological Hydroxylation Sand Ascorbic Acid with Special Regard to Collagen Metabolism. Vitamins Hormones, 30, 1-43.

[11] Barnes, M.J., Constable, B.J., Morton, L.F. and Kodicek, E. (1970) Studies in Vivo on the Biosynthesis of Collagen and Elastin in Ascorbic Acid Deficient Guinea Pigs. Evidence for the Formation and Degradation of a Partially Hydroxylated Collagen. Biochemical Journal, 19, 575-585.

[12] Neuman, R.E. and Logan, M.A. (1950) The Determination of Hydroxyproline. Journal of Biological Chemistry, 184, 299.

[13] Levine, M. (1986) New Concepts in the Biology and Biochemistry of Ascorbic acid. New England Journal of Medicine, 314, 892-901. http://dx.doi.org/10.1056/NEJM198604033141407 